\title{
Analisys Multitemporal Changing Mangrove's Area at Belitung Regency Bangka Belitung Island Province, Indonesia
}

\author{
Beni Aulia \\ College Student of Magister Program of Geography Education \\ Faculty of Social Science, Universitas Negeri Padang \\ Email: beni_aulia@ymail.com
}

\begin{abstract}
The purpose of this research is to know the change of mangrove land at Belitung district by using remote sensing for mangrove land changes in 2001 and 2016 (multitemporal). Radiometric correction on this research aims to improve the quality of the image and at the same time improve the pixel values that do not correspond to the actual spectral values, dgunakn image is Landsat 7 Landsat 82001 and 2016. The composite image is used on the research of composite RGB bands 4, 5, and 3 for Landsat 7 as for Landsat 8 used composite RGB 5, 6 and 4. This research uses software ENVI 4.5 and Arcgis 10.1. The result of the interpretation of the map changes in the region. Mangrove forest area in 2001 was 10,032.75 Ha and 9,779.4 Ha found 2016. So, the shrinkage of mangrove land that is the lowliest coastal Belitung district is 253.35 ha.
\end{abstract}

Keywords: Remote Sensing, Mangrove, Multitemporal

\section{Introduction}

Mangrove plant forms are characteristic of the coast, estuaries or River estuary, and delta in a place sheltered tropical and sub tropical (Mulyadi et al, 2010). Mangrove forests is one form of forest ecosystems that are unique and distinctive, there is in the area of tidal coastal areas, beaches and small islands or, and is a potential for a very natural resources potential. Mangrove forests have ecological and economic value is high, but very prone to breakage if you lack wisdom in maintaining, preserving and its management (Novianty, et al, 2011). Mangrove ecosystems are ecosystems that are important in the coastal area because it functions ecologically as well as economically. Mangrove ecosystems are also important along with the issue of climate change and carbon trading, because of the mangrove ecosystems became one of the carbon stock of storage large enough. Increased awareness of the mangrove ecosystem will be doing the rehabilitation and management of mangrove areas increases as well. The utilization of remote sensing data for application of mangrove forests has progressed well, but keep going trend of increased scale mangrove information needs more detailed information, for example information spatial types of mangrove. Besides being useful for the management and preservation of spatial information, the type of mangrove is also useful in the study of the estimation of biomass and carbon content, because the biomass and carbon content associated with the different types of mangrove species. Therefore, the research and development of extraction information to identify species or at least zoning (dominant species) are very necessary (LAPAN, 2015).

According to Santoso (2007) the damage of mangrove forests along the coast of Bangka Belitung needs to be immediately addressed in earnest. Many of the damaged mangrove forests for example on wood charcoal, coconut, Bangka Barat. It is usually cut down mangrove land for mining digs the unconventional. As a result the dock Ebony started damaged by abrasion. It also occurs in estuaries Kurau, Koba, Bangka Tengah, and watersheds (DAS) Perimping, Riau Silip, Bangka. The result of the destruction of mangrove forests, among others, the decline in the population of crabs, small crab attaching the animals and their habitats in the estuary. According to the Department of agriculture and forestry of Bangka Belitung, 
extensive mangrove forests damaged by mining and logging around 36.000 hectares of a total of 120,000 ha of mangrove forest. As an ecosystem that is between land and sea, mangroves have an important ecological function. This ecological function can be reviewed from several aspects, including aspects of the physical, chemical, and biological. The physical aspect includes its ability to dampen a wave of the sea, holding mud, and protect from abrasion. When are reviewed from the chemical aspect, mangroves have a role as an absorber elements of polluters, as an energy source, and as a manufacturer of organic materials. While the biological aspect, the mangrove is very important as a place of foraging for food, shelter, and the development of a wide range of biota TNC and P4L (2003).

\section{Method}

Radiometric correction on this research aims to improve the quality of the image and at the same time improve the pixel values that do not correspond to the actual spectral values. Geometric corrections done before doing the first cutting of the image corresponds to the boundaries of the area of research. Geometric correction technique for the good image of Landsat 7 Landsat 82001 and 2016 is already rectified in geometry, meaning that the researchers did not do in geometry correction technique again. Projection system used is the UTM Grid System, Transverse Mercator Projection. Before doing the engineering classification of social interactions (Supervised Classification) the first dikomposit image aims to ease in making training area. The composite image is used on the research of composite RGB bands 4, 5, and 3 for Landsat 7 as for Landsat 8 used composite RGB 5, 6 and 4. The next step that is looking for a training area of the ROI (Regiont of Interest) or the pilot area that will serve as a reference. ROI manufacturing is done by making a polygon on objects/areas that serve the ROI. Name-name of the object type with the adjusted ROI is known. On retrieval pixel perkelas example in practice is recommended 10 times the number of bands $(\mathrm{N})$ or 100 or even 10 N N (Swain and Davis, 1978 in Rahmi 2009). After having analyzed visually, quantitative analysis was conducted to find out the level of detachment each kind of closure the land. Quantitative analysis to measure the level of detachment each class of land-use separabilitas index closing Transformed Divergence (TD). The values range from 0 to 2.0 would indicate how well couples ROI selected by separate statistics. Then in the final stages of overlays a map of land cover map i.e. 2001 land cover map and 2016 so formed new land units especially in the area of mangrove forests will look lahankhususnya caps change the closure of land of mangrove forests. The result of the classification of the closure of the land area of the County and overlay of both Belitung map then it will get a map of the area of Mangrove 2016, but this map is still a tentative map or still is the result of prediction of interpreters, so it must need to be confirmed. Then in the final stages of overlays a map of land cover map i.e. 2001 and land cover map of 2016, thus formed a new land units especially in the area of mangrove forests will be visible changes in land cover in particular the closure of the mangrove forest land.

\section{Results and Discussion}

Mangrove forests is one form of forest ecosystems that are unique and distinctive, there is in the area of tidal coastal areas, beaches and small islands or, and is a potential for a very natural resources potential. Mangrove forests have ecological and economic value is high, but very prone to breakage if you lack wisdom in maintaining, preserving and its management (Novianty et al, 2011). Based on the results of the analysis of the interpretation of Landsat 7 imagery in 2001 and Landsat 82016 with engineering classification of social interactions. This data processing using Envi software 4.5 and Arcgis 10.1 as making layout and overlay the second map. The result of the interpretation of images obtained seven types of land cover classes i.e. low intensity forests, forests of medium intensity, high intensity, forest settlements, mangrove, scrub and open land. Based on the results of the analysis of the remote sensing image of landsat 7 imagery i.e. 2001 and Landsat 8 year 2016 and survey the field produces the map changes the area of Mangrove Forests in 2001 and 2016. The result of the interpretation of the map changes in the region. 
Mangrove forest area in 2001 was $10,032.75 \mathrm{Ha}$ and 9,779.4 Ha found 2016. So, the shrinkage of mangrove land that is the lowliest coastal Belitung district is $253.35 \mathrm{Ha}$.

Changes in mangrove forest area is mostly on the coastal areas and estuaries found in district Mebalong, Tanjung Pandan and Sijuk changes the area of the local community to convert mangrove land that serve as open land (Tin mines) in the village of padang kandis, mentigi, membalong, seliu, perpat and mount riting. In addition to the changes the area of mangrove forests into Tin mines and localities have also identified changes from other land cover land cover into the mangroves. Widespread closures of land (landcover) Membalong and sijuk in Belitung district relating to mining Tin, whereas in tanjung pandan mangrove land be used as embankment. Several classes of closure of land might be changed relatively quickly compared to other classes. Classes of relatively rapid change is usually located on the type of land use as an area of cultivation as farming and fishing. Sub Membalong tin mining was the location of an embankment embankment the largest Orchid dikacematan results from interviews on the local community. In addition to the Foundation of the land farmed area of mangrove forests also serve as localities such as that found in the village of Ilodulunga which lies on the coast.

Damage the mangroves in Belitung district can be said to be quite severe, because of the results of the survey and interview there has been no action either from the Government or the community to conserve plants magrove very instrumental especially the coastal areas. With a replant mangrove extinct primarily the coast. Not just meruak and take kentungan of the Tin mines.

As a result of the mangrove area map overlay in 2001 and 2016 there is also a change from another land closure turns into mangrove forests as agricultural land turned into a mangrove forest, the forest of intensitanrenda and medium, as well as land in 2001 is open land now planted with mangrove trees such as those in district nasik Strait.

Mangrove ecological benefits such as the natural protector of the beach from abrasion, accelerate the sedimentation of sea-water intrusion, control, and protect the area behind the mangroves from high waves and strong winds, the place memijah, foraging for food, and shelter for fish, shrimp, crabs and other sea life. While the economic benefits of mangrove as foodstuffs, drinks, medicines, natural dyes, and as an object of Ecotourism (Herwindya, et al, 2001). The vegetation found in the brackish forest ecosystems dominated by plants that have a root of breath or pneumatofora (Indriyanto, 1990, 2005). In addition, the species of plants that live in the forest ecosystems is brackish species of plants that have a high adaptability towards salinity brackish and must live on the environmental condition so called foliage plant species obligate halophytes (Indriyanto, 2005). Plants that generally is a species of tree that can reach a height of $50 \mathrm{~m}$ and only form one stratum heading, so generally it is said that in the brackish forest there is no stratification header in as in the types of the other forest ecosystems.

Remote sensing is the science and art in object information area or even a natural phenomenon through an analysis of data obtained from devices (sensors and platforms) without direct contact with object, Prahasta (2009). The development of remote sensing technologies mainly on spatial resolution and temporal resolution make it easier on mangrove plants identification process. So too with the various techniques of identification can lead to differences of results in the process. Therefore, the necessary agreements on the Method to be used for the process of identification of mangrove plants so that the result will be the same (LAPAN, 2015). The entire system of remote sensing requires energy sources both active (e.g., radar remote sensing system) or passive (e.g. satellite remote sensing systems, optical). The electromagnetic spectrum is the electromagnetic energy of the files include gamma rays, $\mathrm{x}$, ultraviolet, visible, infrared, microwaves, and radio waves. Electromagnetic spectrum commonly used in remote sensing is a portion of the ultraviolet spectrum $(0.3$ to $0,4 \mathrm{~mm})$, the spectrum looks $(0.4 \mathrm{~mm}-0.7 \mathrm{~mm})$ near infrared spectrum $(0.7 \mathrm{~mm}-1.3 \mathrm{~mm})$, thermal infrared spectrum (3-18 mm), and microwave $(1 \mathrm{~mm}-1 \mathrm{~m})$.

Remote sensing in mangrove vegetation is based on two important properties that mangroves grow in the coastal area and substance leaves green (chlorophyll). Optical properties of absorbing the rays of the 
spectrum of red and very strong reflecting the infrared spectrum. Phytoplankton chlorophyll located at sea can be distinguished from chlorophyll mangroves due to the nature of the water that absorbs the infrared spectrum. Soil, sand and rocks also reflects infrared but these materials don't absorb red light beam so that land and mangrove in optics can also be distinguished. How to differentiate mangrove vegetation and nonmangrove by looking away from the beach. The vegetation is both sometimes separated by other objects such as residential, vacant land, farm (Susilo, 2000). Formulation of the problem in this research is how big the change of mangrove area in Belitung district using multitemporal remote sensing imagery. This research aims to know the change of mangrove area in Belitung district using multitemporal remote sensing.

\section{Conclusion}

Based on the results of the interpretation of Landsat 7 imagery in 2001 and Landsat 8 year 2016, as well as the results of checking of field researchers concluded that the occurrence of changes in mangrove area, where extensive mangrove forests in 2001 amounted to 10,032.75 Ha and 9,779.4 Ha found 2016, so reduced by 253.35 Ha. Scattered along the coastal subdistrict of Tanjung Pandan, Membalong and Sijuk. Judging from the results of the changes in land coverage area of mangrove forests can be said to be too large as seen from the difference changes quite so big, but still need to look out for to avoid the larger changes in the future. Based on the results of this research suggest the author in data-processing satellite images landsat satellite imagery in particular to make it more thorough and has a reference in classification so that the resulting data is more accurate. In addition to let readers get the information up to date. For future research on changes of the region either area or other areas of mangrove can use Vegetation index method to find out the level of density of the vegetation. In addition the author suggests to the Government of Belitung district especially in the subdistrict of Membalong so that people not in use the forest area is mainly the area of mangrove forests is good for to tin mining, land use agriculture or fisheries. Need for the suitability of the land that is truly suitable for agricultural land and fisheries.

\section{Reference}

Bengen, D. G. (2001). Pedoman Teknis Pengenalan dan Pengelolaan Ekosistem Mangrov. Pusat Kajian Sumberdaya Pesisir dan Lautan (PKSPL). IPB. Bogor

Forestian, O. (2011). Estimasi Biomassa dan Kerapatan Vegetasi Mangrove Menggunakan Data Landsat ETM+. Fakultas Kehutanan Institut Pertanian Bogor (1-62)

Herwindya, A.Y dan E. Winarti. (2014). Analisis Manfaat Mangrove dan Terumbu Karang Terhadap Lingkungan Pesisir Serta Implikasinya Pada Pendapatan Nelayan (Studi Emperik Pesisir Pantai Demak). Jurnal Ekonomi Manajemen dan Akuntansi. No. 36 / Th. XXI / April 2014. Universitas Indonesia. Depok

Lembaga Penerbangan dan Antariksa Nasional (LAPAN). (2015). Buku Pedoman Teknik Pengolahan data Pengindraan Jauh Landsat 8 Untuk Mangrove. Jakarta

Lillesand, T.M dan R. W. Kiefer. (1990). Pengindraan Jauh dan Intepretasi Citra. Terjemahan. Gajah Mada University Press. Yogyakarta

Mulyadi, E., O. Hendriyanto, dan N. Fitriani. (2010). Konservasi Hutan Mangrove Sebagai Ekowisata.Jurnal Ilmiah Teknik Lingkungan Vol.1 Edisi Khusus

Novianty, R., S. Sastrawibawa., dan J.D. Prihadi. (2011). Identifikasi Kerusakan dan Upaya Rehabilitasi Ekosistem Mangrove di Pantai Utara Kabupaten Subang.

Phihastuti, U. (2009). Pemanfaatan Sistem Informasi Geografis (GIS) dalam Pemetaan Sebaran Mangrove di Pesisir Cirebon Jawa Barat. UPI. Bandung.

Prahasta, E. (2009). Sistem Informasi Geografi Konsep-Konsep dasar (Perspektif Geodesi dan Geomatika). Informatika. Bandung

Puspita, L et al. (2005). Lahan Basah Buatan di Indonesia. Wetlands International - Indonesia Programme. Bogor

Rahmi, J. (2009). Hubungan Kerapatan Tajuk dan Penggunaan Lahan Berdasarkan Analisis Citra Satelit dan Sistem Informasi Geografis di Taman Nasional Gunung Leuser. Skripsi Departemen Kehutanan Fakultas Pertanian Universitas Sumatera Utara Medan(1- 57) 
Refrial., R. Adviana, B. Koswara, dan H. Hamdani. (2012). Analisis Perubahan Luasan Hutan Mangrove Di Jawa Barat Dengan Menggunakan Data Citra Satelit. Universitas Padjarjaran. Bandung

Santoso, U. (2007). Masalah Lingkungan Dan Solusinya Di Propinsi Bengkulu, Bangka Belitung Dan Lampung. Pusat Penelitian Lingkungan Hidup. Diskusi Pusat Studi Lingkungan Hidup dengan Lembaga Pengelola Lingkungan Hidup Daerah. Universitas Negeri Bengkulu

Sri Hardiyanti, P. (2001). Interpretasi Citra Digital. Grasin. Jakarta

Sukmawan, D. (2004). Penilaian Ekonomi Manfaat Hutan Mangrove di Desa Kalangjaladri Kecamatan Parigi, Kabupaten Ciamis, Provinsi Jawa Barat. IPB. Bogor

\section{Beni Aulia}

College Student of Magister Program of Geography Education Faculty of Social Science, Universitas Negeri Padang

Email: beni_aulia@ymail.com 